\title{
Significance of Strategic Management in the Development of International Businesses-A Visionary Approach
}

\author{
Azzam A. Abou-Moghli ${ }^{1}$ \\ ${ }^{1}$ Department of Business Administration, Faculty of Business, Applied Science Private University, Amman, Jordan \\ Correspondence: Azzam A. Abou-Moghli, Department of Business Administration, Faculty of Business, Applied \\ Science Private University, Amman, Jordan.
}

Received: June 19, 2018

Accepted: July 30, 2018

Online Published: August 17, 2018

doi:10.5430/ijba.v9n5p71

URL: https://doi.org/10.5430/ijba.v9n5p71

\begin{abstract}
Organizations face endless obstacles for the protection of current marketplace and market shares. Strategic management act as a contributing factor to make stream of movements towards sustainable successive operational business development in the international business. Therefore, the present study has discussed the significance of strategic management in the development of international businesses. The study results have shown that existing financial institutions are improved and new firms within international market are emerged as a result of rapid development of financial market. The successful transition for initiating tactical adjustments on the basis of preconceived scenarios is guaranteed through the integration of acts of strategic development. Moreover, the development of strategic plan needs a great deal of strategic thinking to bring the organization's aim to fruition. The goals of strategic marketing are achieved by ensuring a strong focus on the customer needs. The marketing tools utilized by majority of the organizations to achieve competitive advantage include; loyal customer relationship, innovation, alliances, and communication. The international strategic management tends to drive strategies of successful businesses within diverse market environment. The results have concluded that organization can gain success by developing strategic alliance with companies of similar field of operation. Moreover, mostly companies have successfully modified and created new expansion strategies to enter the marketplace.
\end{abstract}

Keywords: strategic management, international businesses, international market, sustainable operation, global economic crisis, organizational competitiveness

\section{Background}

There are endless collisions between businesses that seek to enter new markets for the protection of current marketplace and market shares. Every industry is facing the consequences of global competition. The organizations dominating in the international markets need to reckon with innovative and aggressive competitors across the globe (Hahn, 2015). It is important to note that majority of the businesses tend to accommodate certain conditions and circumstances within the boundaries of native country. A study conducted by Gashi (2017) has shown that large markers need to have different operational commitments in order to succeed. The international market act as a gate to a number of opportunities for expanding business through the implementation of appropriate strategic planning. However, the expansion of business intends a sustainable operation along with the selected strategy, no matter the headway has a number of significant hindrances to overcome. The need of developing strategic planning was determined after the global economic crisis $(2008$ - 2010) and financial crisis in Russia (2014 - 2015). In this situation, mostly companies were not ready for unpredictable change in the economic environment (Bondarenko et al., 2017).

The methods of strategic management are not used adequately, despite of having qualified specialists and opportunities to organize their involvements in establishing country's economy. It is important to study the significance of strategic management for stipulating the need of using different strategies to manage companies to cope up with the modern conditions. Strategic management within an organization depends on personnel potential and its production activity that relate to the client's demand. It helps to achieve competitive advantage within the perspective of its development (Bondarenko et al., 2017). The development of strategic management within an organization is associated with the identification of basic components that include; market opportunity, company values, company potential, and approved obligations. Performing adequate economic activity helps the organization 
to meet its external needs. Strategic management is likely to provide strict compliance of opportunities provided to the enterprise along with their external needs.

A study conducted by Abraham (2012) stated that strategic management in developing international business is important as it act as a contributing factor to make stream of movements towards sustainable successive operational business development. In the light of this study, the present study aims to determine the significance of strategic management in the development of international businesses. Therefore, the present study has mainly focused on the significance of strategic management in the development of international businesses. It is necessary to develop the financial market rapidly to improve the existing financial institutions and emergence of new firms in the market. The study results can be used by majority of the businesses that aspire to enter the major global markets.

\section{Research Questions}

1. What are the key elements adopted by a company to employ strategic management under unstable economic conditions?

2. How can organizations forecast and develop strategies under turbulent conditions?

3. How can organizations develop optimal system to engage strategic management for stabilizing economic conditions within the country?

\section{Strategic Thinking and Planning}

A solid business operation requires initiation of strategy modification and improvement in strategic thinking as its base. Basically, strategic development is defined as shifting to an elite group from traditional functioning within a company, in which the approaches towards strategic thinking are aggregated into cohesive set of strategic corporations. These strategic initiatives are driven on the basis of changes sensed in the business environment. The organizations need to integrate the act of strategic development to make successful transition for initiating tactical adjustments on the basis of preconceived scenarios (Gashi, 2017). The development of strategic plan needs a great deal of strategic thinking to bring the organization's aim to fruition.

In order to achieve success, organizations do not only need to get engaged in strategic planning, rather it needs to think and manage the operations strategically (Nickols, 2016). A solid business operation requires strategic modification and improved strategic thinking as its basement. Within an organization, strategic development is associated with shifting from a traditionally restricted function to an elite group. The changes within a business environment drives the cohesive set of strategic initiatives that aggregates the strategic thinking across different organizations (Sloan, 2013). The act of strategic development is integrated by majority of the organizations to achieve success by initiating tactical adjustments on the basis of preconceived scenarios.

The main purpose of strategic development is to gain and sustain competitive advantage and cope up with the plausible strategic alternatives. This approach should not just be implemented within an organization, when it gets engaged in strategic planning, rather this approach should be implemented and valued all the time. It is important to understand how the markets and competitors tend to attain different opportunities for determining the best strategic alternative to achieve competitive advantage (Abraham, 2012). Five major components involved in consistent strategic planning for the businesses are; analysis, formulation, planning strategies, execution, and continuous improvement in previous strategies (Simerson, 2011). Strategic planning being the backbone of strategic management is associated with management and operational planning to develop effective ideas to achieve competitive advantage (Simerson, 2011).

There is a need to implement progressive management methods within companies for their active development. Moreover, implementation of efficient process of strategic planning is required for transmitting information and bringing about rapid changes within the service provision technologies (Cassidy, 2016). Therefore, it is necessary to indulge in strategical development for providing mechanism of its fulfillment and conducting effective measures (Bondarenko et al., 2017). It is important to modernize processes and services as a response to changing needs of clients through impetuous development of different organizations. This needs constant improvement and changes in business processes and services. The task of managers to take strategic decisions is complicated as a result of emergence of a number of indefiniteness factors prevailing in the external environment (Yilmaz \& Flouris, 2017). The organization need to consider all the pros and cons of a strategy before its planning and implementations for stabilizing unstable conditions (Banihabib et al., 2015).

The global financial crisis has aggravated the modern instability of market system, which has provoked unemployment, fall of productions, and decreased investments. The markets facing high level of interest rates, 
inflation, low investment attractiveness in majority of the sectors, and imperfection of legislative base need to tackle the problems related to strategic management (Leigh \& Blakely, 2016). Managers are likely to seek for new solutions and strategies for counteracting risks associated with rapid changing factors within the external environment. The increased impact of social and political impact has complicated the process of taking appropriate and effective decisions by the managers. However, it is believed that these changes not only bring difficulties but it raises new opportunities for the under-developed organizations. Stable development within smooth fluctuations of external environment is likely to be achieved through competent strategic management by taking in account the possible risk and methods to overcome the risks to achieve desired goals (Booth, 2015; Bondarenko et al., 2017).

\section{Marketing Techniques}

Identifying and creating value for business by strongly differentiated positioning is the major role played by strategic marketing. The organizations achieve this by affecting the culture of organization and their strategical operations to ensure a strong consumer focus. These techniques use tools like customer relationship, brands, alliances, innovation, and communications to develop a specific competitive position (Gashi, 2017). These factors are important as strategic marketing defines how an organization competes being part of marketing itself. Organizations use different marketing tools including; loyal customer relationship, innovation, alliances, and communication to develop a specific competitive position. The concept of strategic management is considered as a significant distinction that helps the organization to compete in the global market.

Two main issues regarding entering the global market are sought by strategic marketing. Due to the connection of strategic marketing with marketing orientation as a strategic perspective, it is best suited for the businesses that aim to enter the wide markets. Consistent focus by the employees is required for the characterization of oriented businesses at all levels of consumer needs and competitive circumstances (Sahaf, 2008). The factors affecting the strategic development within the organization are represented in Figure 1.

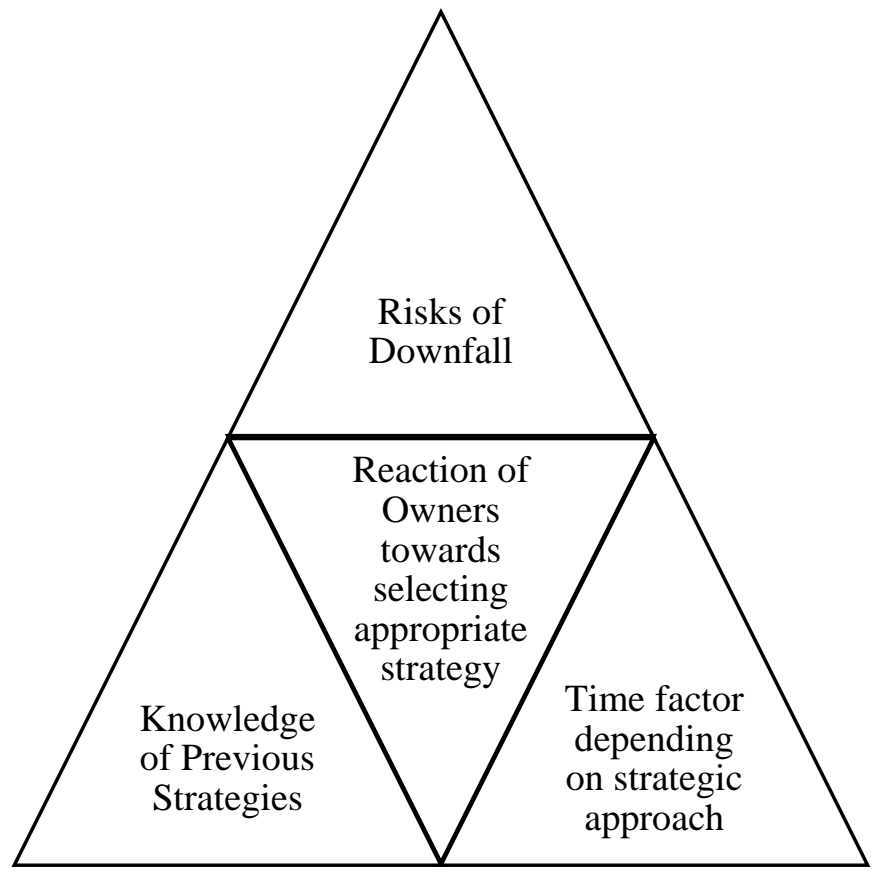

Figure 1. Factors affecting strategic development within different organizations

\section{Strategic Management in International Business}

Different organization have realized the importance of increased number of emerging markets as they are source of inexpensive labor to the source market since the last decade. The development of appropriate business strategy ensures that the organization has developed and retained necessary skills and competencies to make the strategy successful. Strategic alliances provide appropriate mechanism to hedge risks by enabling product diversification, lowering total investments, enabling faster market entry, and combining slack facilities and expertise (Gashi, 2017). The efforts of companies in emerging countries are accelerated to integrate themselves in the global economy. International strategic management tends to drive strategies of successful businesses within diverse market 
environment (Lasserre, 2017). Moreover, it is believed that businesses need to take into account some features that are encountered based on current dramatic changes within the global market environment. Some of the dramatic changes have been mentioned below (Lasserre, 2017);

- Strategies associated with international business management involve certain strategic alliances and inter-organizational teams globally that functions to redirect the focus of company towards customer and global competition.

- Strategic management is considered as a significant process to gain competitive advantage through active participation.

- Active support, commitment, and involvement of top management is needed for the integration of appropriate business practices.

- The existence of trade blocks results in the development of international strategies under certain situations.

According to Aaker and McLoughlin (2010), development of right business strategy is the main aim of an organization. However, continuous challenges are likely to be faced despite of proper business strategy in hand. This makes sure that the situation remains relevant towards the changing marketplace and emerging opportunities within the marketplace. Any strategy can be successful by ensuring that the organization develops and retains necessary competencies and skills (Bryson, 2018). The easiest path of success with less strategic concerns and international strategic alliance has been perceived as a vivid outlook that is linked with strict policies and requirements to access new markets for sustainable presence and international expansion (Bryson, 2018). Strategic alliance with companies of similar field of operation is known as the best and most appropriate strategy to gain success in marketplace (Gashi, 2017).

Buckley (2016) stated that strategic alliances are considered as a proper mechanism to hedge risks and are responsible for identifying different ways to reduce risks. The intensity and frequency of developing risks are reduced as a result of enabling fast market entry, product diversification, and lowered cost of total investments by combining slack facilities and expertise. The comparative advantage of each partner within business can be used for reducing the total cost of desired product or approach through international strategic alliances (Brouthers et al., 2015). The production can be transferred to lower costs belonging to different locations and countries to create greater comparative advantage. If the demand of certain products in a particular region are limited, lowered costs is considered as an incentive for companies to emphasize on the sale economies (Buckley, 2016). The strategic alliance as a part of international managerial strategy is responsible for accelerating the way in which businesses are provided with golden opportunity to achieve long-term goals (Hill et al., 2014). Thereby, long-term goals are likely to be achieved through market expansion and conducting international trade.

\section{Conclusion}

The study may conclude that it is important to apply the most effective strategy through proper strategic marketing needed for entering in the new market. Some distinguishable points apart from the aims and objectives of majority of the organizations are considered while preparing their business plans. In the same context, mostly companies have successfully modified and created new expansion strategies to enter the marketplace. Apart from some regional deals made by the organizations in past, some of the organizations struggle to face the hard times for developing appropriate strategies towards long-term operation in closed market. The activities prevailing within an organization are shaken as a result of economic instability resulting in significant strategic transformations.

Constant change related to ability of organization to develop, competition, and legislation is provoked by elemental market mechanism concerning the economic instability. Organizations are provided with significant opportunities through such changes. The study has clearly shown that it is necessary to stimulate the organization's management for improving strategic management that allow new opportunities to counteract risks. The instability of organizations is likely to result in disturbed economic development of the country. Consideration of strategic changes for the development of efficient strategic plan enable an organization to observe the final consequences associated with aggregation of diversified business processes. These business approaches are likely to result managerial impact on the organization along with the help of strategic decisions. Strategic plan can be framed by aggregating the solutions offered in the present study. Future studies need to focus on the challenges and obstacles faced by the organizations in the implementation of strategic plan. 


\section{Acknowledgements}

The author is very thankful to all the associated personnel in any reference that contributed in/for the purpose of this research.

\section{Conflict of Interest}

The author declares no conflict of interest.

\section{Funding}

The study is not funded through any external source

\section{References}

Aaker, A.D., \& McLoughlin, D. (2010). Strategic Market Management-Global Perspectives. John Wiley \& Sons, Ltd. West Sussex, UK.

Abraham, S.C. (2012). Strategic planning: a practical guide for competitive success. Emerald Group Publishing.

Banihabib, M.E., Azarnivand, A., \& Peralta, R.C. (2015). A new framework for strategic planning to stabilize a shrinking lake. Lake and Reservoir Management, 31(1), 31-43. https://doi.org/10.1080/10402381.2014.987409

Bondarenko, T.G., Isaeva, E.A., Orekhov, S.A., \& Soltakhanov, A.U. (2017). Optimization of the Company Strategic Management System in the Context of Economic Instability. European Research Studies, 20(2), 3.

Booth, S.A. (2015). Crisis management strategy: Competition and change in modern enterprises. Routledge.

Brouthers, K.D., Nakos, G., \& Dimitratos, P. (2015). SME entrepreneurial orientation, international performance, and the moderating role of strategic alliances. Entrepreneurship Theory and Practice, 39(5), 1161-1187. https://doi.org/10.1111/etap.12101

Bryson, J.M. (2018). Strategic planning for public and nonprofit organizations: A guide to strengthening and sustaining organizational achievement. John Wiley \& Sons.

Buckley, P.J. (2016). International strategic management and government policy. Springer.

Cassidy, A. (2016). A practical guide to information systems strategic planning. CRC press.

Gashi, R. (2017). Strategic Management Key to Success for Kosovo Companies-Expansion in International European Market. European Center for Science Education and Research, 62.

Hahn, J. (2015). Stabilisation and Association Agreement (SAA) between the European Union and Kosovo signed. Foreign affairs \& International Relations, Council of the European Union.

Hill, C.W., Jones, G.R., \& Schilling, M.A. (2014). Strategic management: theory: an integrated approach. Cengage Learning.

Lasserre, P. (2017). Global strategic management. Macmillan International Higher Education.

Leigh, N.G., \& Blakely, E.J. (2016). Planning local economic development: Theory and practice. Sage Publications.

Nickols, F. (2016). Strategy, Strategic Management, Strategic Planning and Strategic Thinking.

Sahaf, M.A. (2008). Strategic marketing: making decisions for strategic advantage. PHI Learning Pvt. Ltd.

Simerson, B.K. (2011). Strategic planning: A practical guide to strategy formulation and execution. ABC-CLIO.

Sloan, J. (2013). Learning to think strategically. Routledge.

Yilmaz, A.K., \& Flouris, T. (2017). Enterprise risk management in terms of organizational culture and its leadership and strategic management. In Corporate risk management for international business (pp. 65-112). Springer, Singapore. https://doi.org/10.1007/978-981-10-4266-9_3 